Click www.researchjournal.co.in/online/subdetail.html to purchase.

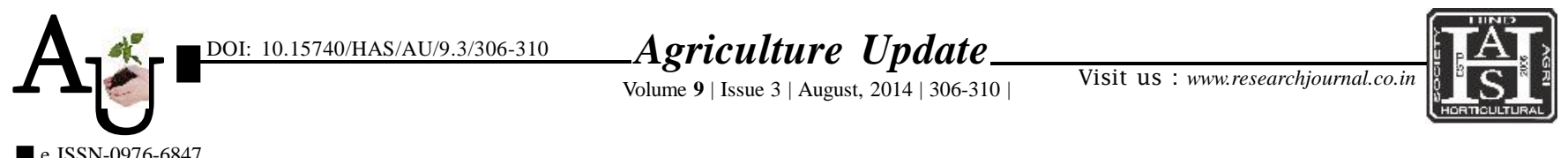

Research Article

\title{
Knowledge level of beneficiary and non- beneficiary farmers about improved groundnut production technology
}

\author{
M.V. POKAR, R.M. JAVIA AND G.K. SAPARA
}

Article Chronicle: Summary : The study was undertaken in Banaskantha district of Gujarat to know the knowledge level of Received :

10.05.2014;

Revised :

27.05.2014;

Accepted :

14.06.2014

farmers about groundnut production technologies under FLD on a sample of 70 beneficiary and 70 non-beneficiary farmers. It was observed that maximum number of beneficiary farmers (55.72\%) and non-beneficiary farmers $(62.86 \%)$ had medium level of knowledge about groundnut production technologies, where as 35.71 per cent beneficiary farmers and 4.28 per cent non-beneficiary farmers had high level of knowledge. Significant difference between beneficiary and non-beneficiary farmers with respect to knowledge level were found, it indicates beneficiary farmers had higher level of knowledge as compared to non-beneficiary farmers. Education, annual income, extension participation and scientific orientation had positive and significant association with the knowledge level of improved groundnut production technology.

How to cite this article : Pokar, M.V., Javia, R.M. and Sapara, G.K. (2014). Knowledge level of beneficiary and non- beneficiary farmers about improved groundnut production technology. Agric. Update, 9(3): 306-310.

KeY WoRds:

Groundnut production

technology, Front

line demonstration,

Knowledge,

Correlation

co-efficient

Author for correspondence :

R.M. JAVIA

Krishi Vigyan Kendra

(J.A.U.)

SURENDRANAGAR

(GUJARAT) INDIA

Email: rmjavia@gmail.com

See end of the article for

authors' affiliations 